\title{
Implikasi Undang-Undang Nomor 30 Tahun 2014 tentang Administrasi Pemerintahan terhadap Fungsi Peradilan Tata Usaha Negara
}

\author{
Francisca Romana Harjiyatni dan Suswoto \\ Fakultas Hukum Universitas Janabadra Yogyakarta \\ Jln. Timoho II No. 40 Yogyakarta \\ sisca.rh@gmail.com; suswoto.123@gmail.com
}

Received: 18 Oktober 2017; Accepted: 11 Januari 2018; Published: 5 Juni 2018

DOI: 10.20885 /iustum.vol24.iss4.art5

\begin{abstract}
This study aimed to answer problems related to: 1) How is the implication of the Government Administrative Law on the functions of the State Administrative Court (PTUN), does the existence of the Administrative Law weaken or strengthen the functions of PTUN as an oversight body? 2) Are there any needs to reinforce the functions of PTUN as the absolute competences of PTUN are increasing after the Administrative Court of the Government is applicable? This study was a normative legal research by analyzing primary, secondary, and tertiary legal materials using qualitative juridical approach. This research concludes that: 1) An increasing absolute competence of PTUN might weaken or strengthen the functions of PTUN, depending on the integrity of human resources, including judges; and 2) There is a need to strengthen the functions of PTUN as the absolute competence of PTUN is increasing based on the Administrative Law of Government by: a) immediately amending the Administrative Law in accordance with the Administration Law of Government and increasing the force to execute decisions by establishing an executive body to execute PTUN decisions; $b$ ) increasing the independence of PTUN judges in examining, deciding and resolving any disputes or petitions.
\end{abstract}

Keywords: Government administration; state administrative court; absolut competence

\section{Abstrak}

Penelitian ini bertujuan untuk menjawab permasalahan tentang: 1) Bagaimanakah implikasi UU Administrasi Pemerintahan terhadap fungsi PTUN, apakah keberadaan UU Administrasi Pemerintahan memperlemah atau memperkuat fungsi PTUN sebagai lembaga pengawasan? 2) Apakah perlu dilakukan upaya penguatan fungsi PTUN seiring dengan meluasnya kompetensi absolut PTUN setelah berlakunya UU Administrasi Pemerintahan? Penelitian ini merupakan penelitian hukum normatif, yaitu menganalisis bahan-bahan hukum primer, sekunder, dan tersier. Bahan hukum dianalisis secara yuridis kualitatif. Hasil penelitian menyimpulkan bahwa: 1) Perluasan kompetensi absolut PTUN dapat menimbulkan implikasi memperlemah atau menguatkan fungsi PTUN bergantung pada integritas SDM termasuk hakim; dan 2) Perlu penguatan fungsi PTUN seiring dengan meluasnya komptensi PTUN berdasarkan UU Administrasi Pemerintahan yaitu dengan: a) segera dilakukan perubahan UU PTUN menyesuaikan dengan UU Administrasi Pemerintahan dan meningkatkan daya paksa pelaksanaan putusan dengan membentuk lembaga eksekusi untuk melaksanakan putusan PTUN; b) meningkatkan independensi hakim PTUN dalam memeriksa, memutus dan menyelesaikan sengketa atau permohonan.

Kata-kata Kunci: Administrasi pemerintahan; peradilan tata usaha negara; kompetensi absolut 


\section{Pendahuluan}

Undang-Undang Nomor 30 Tahun 2014 tentang Administrasi Pemerintahan (selanjutnya disebut dengan UU Administrasi Pemerintahan) diundangkan dengan maksud menjadi pedoman dalam penyelenggaraan pemerintahan. Pejabat pemerintahan dalam menyelenggarakan pemerintahan dan pelayanan publik harus mendasarkan pada UU Administrasi Pemerintahan. Hal ini merupakan perwujudan daripada negara hukum. Dalam negara hukum, pejabat pemerintahan dalam menjalankan tindakan maupun membuat keputusan harus berpedoman pada kaidah-kaidah yang diatur dalam UU Administrasi Pemerintahan.

UU Administrasi Pemerintahan merupakan hukum materiil. Hukum materiil merupakan sekumpulan peraturan yang mengatur mengenai hal-hal yang wajib dilakukan, seyogyanya dilakukan, dan tidak dibolehkan (dilarang). ${ }^{1}$ Dapat juga diartikan, hukum materiil adalah peraturan yang berisi tentang hak dan kewajiban. ${ }^{2}$ UU Administrasi Pemerintahan merupakan peraturan yang berisi mengenai hak dan kewajiban dalam penyelenggaran pemerintahan. Dapat juga dikatakan bahwa UU Administrasi Pemerintahan merupakan peraturan yang mengatur mengenai hal-hal yang wajib dilakukan, boleh dilakukan, dan tidak boleh dilakukan (dilarang) oleh pejabat pemerintahan. Dengan demikian dapat disimpulkan bahwa, UU Administrasi Pemerintahan merupakan hukum materiil.

Untuk melengkapi hukum materiil diperlukan hukum formil. Hukum formil adalah peraturan yang mengatur mengenai cara menegakkan hukum materiil jika dilanggar. UU No. 5 Tahun 1986 jo UU No. 9 Tahun 2004 jo UU No. 51 Tahun 2009 (selanjutnya disebut dengan UU PTUN) merupakan hukum formil. Keberadaan UU PTUN ada lebih dahulu dibandingkan dengan UU Administrasi Pemerintahan, akan tetapi isi dari UU PTUN dan UU Administrasi Pemerintahan mengatur halhal yang tidak sama, di antaranya menyangkut kompetensi absolut PTUN. UU Administrasi Pemerintahan memberikan kewenangan absolut pada PTUN yang lebih luas (lebih besar). Dengan kewenangan absolut yang lebih besar, kewenangan PTUN melakukan pengawasan terhadap pejabat pemerintahan juga semakin

\footnotetext{
hlm. 41 .

${ }^{1}$ Sudikno Mertokusumo, Mengenal Hukum Suatu Pengantar, Cetakan Keempat, Liberty, Yogyakata, 2008, 2 Ibid., hlm. 127.
} 
besar. Dengan kewenangan absolut yang semakin besar akan memperbesar pula peluang masyarakat untuk meminta keadilan melalui PTUN, dengan demikian harapan masyarakat untuk mendapatkan perlindungan hukum yang adil dari PTUN juga semakin besar. Dengan kompetensi absolut PTUN yang semakin besar, seharusnyalah fungsi PTUN juga semakin kuat sehingga dapat memenuhi keadilan yang diharapkan dari masyarakat. Dengan kompetensi yang semakin luas dan peluang gugatan yang semakin besar pula kepada PTUN, maka akan mempengaruhi banyak hal, seperti misalnya tekanan dari pihak-pihak yang bersengketa maupun dari pihak lain yang terkait dengan suatu sengketa yang mempengaruhi integritas dan independensi hakim, serta tuntutan akan jaminan bahwa putusan PTUN benar-benar dapat dilaksanakan sehingga keadilan benarbenar dirasakan oleh masyarakat pencari keadilan. Dengan perubahan kompetensi absolut PTUN tersebut, seharusnya dilakukan perubahan UU PTUN untuk menyesuaikan dengan UU Administrasi Pemerintahan. Belum adanya penyesuaian undang-undang tersebut, akan dapat menimbulkan persoalanpersoalan terkait dengan fungsi PTUN dalam menjalankan kewenangan memeriksa, memutus dan menyelesaikan sengketa. Fungsi PTUN kuat apabila ada peraturan perundangan yang jelas dan memberikan kepastian hukum sebagai pedoman pedoman beracara dalam menyelesaikan sengketa. Selain itu, fungsi PTUN kuat apabila dengan memiliki kompetensi absolut yang lebih besar, PTUN mampu menjaga integritasnya sehingga dapat menyelesaikan sengketa dengan baik dan adil bagi masyarakat pencari keadilan, dan putusan PTUN benar-benar dapat dilaksanakan serta dirasakan oleh masyarakat.

\section{Rumusan Masalah}

Permasalahan yang dibahas dalam penelitian ini adalah: Pertama, bagaimanakah implikasi UU Administrasi Pemerintahan terhadap fungsi PTUN, apakah keberadaan UU Administrasi Pemerintahan memperlemah atau memperkuat fungsi PTUN sebagai lembaga pengawasan? Kedua, apakah perlu dilakukan upaya penguatan fungsi PTUN seiring dengan meluasnya kompetensi absolut PTUN setelah berlakunya UU Administrasi Pemerintahan? 


\section{Tujuan Penelitian}

Adapun tujuan penelitian di dalam penelitian ini adalah: Pertama, mengetahui implikasi UU Administrasi Pemerintahan dalam konteks memperlemah atau memperkuat fungsi PTUN sebagai lembaga pengawasan; Kedua, mengetahui urgensi upaya penguatan fungsi PTUN seiring dengan meluasnya kompetensi absolut PTUN setelah berlakunya UU Administrasi Pemerintahan.

\section{Metode Penelitian}

Penelitian ini merupakan penelitian hukum normatif, yang menggunakan data sekunder yang terdiri dari bahan-bahan hukum yang meliputi bahan hukum primer, sekunder, dan tersier. Bahan-bahan hukum yang diperoleh dalam penelitian akan dikumpulkan, dikelompokkan sesuai variabel masing-masing, untuk selanjutnya dianalisis yuridis kualitatif. Metode pendekatan yang digunakan dalam menganalis bahan-bahan hukum yaitu pendekatan perundangundangan (statue approach) dan pendekatan konsep (conceptual approach). Hasil dari penelitian disajikan dalam bentuk preskriptif analitis.

\section{Hasil Penelitian dan Pembahasan}

\section{Implikasi UU Administrasi Pemerintahan terhadap fungsi PTUN}

Dengan berlakunya UU No. 30 Tahun 2014 tentang Administrasi Pemerintahan, kewenangan absolut PTUN mengalami perluasan. Berdasarkan UU PTUN, kewenangan atau kompetensi absolut PTUN terbatas menangani sengketa yang obyeknya KTUN yang tertulis. Lebih detailnya, KTUN sebagaimana dimaksud dalam Pasal 1 angka 3 UU No. 5 Tahun 1986 jo Pasal 1 angka 9 UU No.

51 Tahun 2009 adalah sebagai berikut :

KTUN adalah suatu penetapan yang dikeluarkan oleh Badan atau Pejabat TUN yang berisi tindakan hukum tata usaha negara yang berdasarkan peraturan perundang-undangan yang berlaku, yang bersifat konkrit, individual dan final, yang menimbulkan akibat hukum bagi seseorang atau badan hukum perdata.

Berdasarkan ketentuan tersebut, ditunjukkan bahwa kewenangan atau kompetensi absolut PTUN dibatasi pada KTUN yang tertulis dan bersifat individual, dengan demikian KTUN yang berlaku umum (tidak individual) dan 
tindakan nyata yang dilakukan oleh pejabat pemerintahan bukan menjadi obyek sengketa yang menjadi kewenangan PTUN.

Setelah berlakunya UU No. 30 Tahun 2014, kewenangan absolut PTUN mengalami perluasan. Pernyataan ini disimpulkan dari pendapat Enrico Simanjuntak yang menyatakan, "Dalam UU Administrasi Pemerintahan diatur perluasan kewenangan Peradilan Administrasi”. ${ }^{3}$ Hal ini diperkuat lagi dengan pendapat Yodi Martono Wahyunadi yang mengatakan bahwa "Adanya perubahan konsep hukum yang diatur dalam UU Peratun, memperluas kompetensi PTUN”. ${ }^{4}$ Perluasan kewenangan tersebut adalah sebagai berikut: a. kewenangan yang obyek sengketanya adalah KTUN yang mempunyai kriteria sebagai berikut sebagaimana diatur dalam Pasal 87 UU Administrasi Pemerintahan. Berdasarkan ketentuan tersebut, selain memeriksa, memutus, dan menyelesaikan sengketa yang obyeknya KTUN yang tertulis, PTUN juga berwenang memeriksa, memutus, dan menyelesaikan tindakan nyata yang dilakukan oleh pejabat TUN. Selain itu juga diberikan kewenangan memeriksa, memutus, dan menyelesaikan keputusaan yang berlaku bagi masyarakat; b. kewenangan memeriksa, memutus dan menyelesaikan gugatan tentang ada tidaknya unsur penyalahgunaan wewenang; c. kewenangan memeriksa, memutus, dan menyelesaikan permohonan penerimaan keputusan fiktif positif.

Perluasan kompetensi absolut PTUN akan menyebabkan jumlah kasus yang dimintakan penyelesaiannya oleh masyarakat ke PTUN juga semakin tinggi. Hal ini dapat menyebabkan tekanan, intervensi, pengaruh dari lembaga eksternal maupun dari para pihak juga semakin tinggi. Intervensi terhadap hakim yang mengadili dalam perkara yang obyeknya berdasarkan UU Administrasi Pemerintahan disampaikan sebagai berikut:

Agar proses persidangan dapat berjalan dengan baik serta putusan berpihak pada keadilan harus dilakukan penyesuaian terlebih dahulu. Pada proses peradilan yang pertama UU ini, yaitu yang melibatkan PT TUN Medan dan pengacara kondang O.C. Kaligis ternyata menimbulkan masalah. Hakim dan

${ }^{3}$ Enrico Simanjuntak, "Beberapa Anotasi Terhadap Pergeseran Kompetensi Absolut Peradilan Umum Kepada Peradilan Administrasi Pasca Pengesahan UU No. 30 Tahun 2014”, Bunga Rampai Peradilan Administrasi Kontemporer, Genta Press, Yogyakarta, 2014, hlm. 59.

4 Yodi Martono Wahyunadi, "Kompetensi Absolut Pengadilan Tata Usaha Negara Dalam Konteks Undang-Undang Nomor 30 Tahun 2014 Tentang Administrasi Pemerintahan”, artikel dalam Jurnal Hukum dan Peradilan, Volume 5, Nomor 1, Maret 2016, hlm. 141. 
pengacara terlibat kasus suap dan saat ini sedang diperiksa oleh KPK. Hal ini menandakan rentannya UU ini terhadap penyalahgunaan jika tidak dibarengi dengan perbaikan sumber daya manusia. ${ }^{5}$

Berdasarkan pendapat tersebut menunjukkan bahwa, dalam proses peradilan yang perkaranya mendasarkan pada UU Administrasi Pemerintahan telah terjadi kasus suap, yang menunjukkan bahwa integritas hakim rendah dan mudah dipengaruhi para para pihak khususnya pemohon dalam memutus perkara. Adanya kasus suap dalam penanganan sengketa yang mendasarkan pada UU Administrasi Pemerintahan tersebut, memperlihatkan bahwa fungsi PTUN yang semakin lemah, karena PTUN tidak dapat berfungsi untuk mendorong terwujudnya pemerintah yang bersih dan berwibawa.

Perluasan kompetensi absolut pengadilan akan memperkuat atau memperlemah fungsi PTUN tergantung pada independensi pengadilan termasuk hakim-hakim maupun staf pengadilan yang lain. Pentingnya independensi lembaga peradilan adalah sebagai berikut:

Judicial independence is often misunderstood as something that is for the benefit of the judge. It is not. It is the public's guarantee that a judge will be impartial. Judicial independence protects individuals and the community. The protection of judicial independence is enforced so that the parties will know they were dealt with fairly, that they received a fair trial, and a fair hearing from a judge insulated from any improper outside influence and who was bound only by his or her oath of office, nwhich is to render justice according to law. To be efficient and meet its objective, judicial independence must also protect judges. Judges have a responsibility to protect their independence and impartiality. They do so not out of self-interest, but as an obligation to the public, which has entrusted them with decision-making power and to whom they are ultimately accountable to maintain the public's confidence in the justice system. The protection of judicial independence is intended to go much farther than simply any particular case or any particular persons who cannot otherwise resolve their problems. The protection is for the entire community. It is a public trust. The community must have confidence in its system of justice and be comfortable in the knowledge that fairness, openness, and immunity from improper influence are characteristics of its judiciary. In this way, the community will believe that all citizens can expect the same treatment according to the Rule of Law [What is the "Rule of Law?"6

5 Despan Heryansyah, "Pergeseran Kompetensi Absolut PTUN Dalam Sistem Hukum Indonesia”, artikel dalam Jurnal Hukum Novelty, Vol. 8 No. 1 Februari 2017, hlm. 47.

6 "Why is Judicial Independence Important to You?" http://www.cjc-ccm.gc.ca/cmslib/general, diakses tanggal 27 Juli 2017, hlm. 6. 
Independensi pengadilan penting untuk masyarakat, sehingga masyarakat mendapatkan jaminan akan memperoleh perlindungan yang adil dari lembaga peradilan. Keberadaan pengadilan tanpa dilengkapi dengan independensi dari dari hakim dan pegawai pengadilan lainnya, maka keberadaan lembaga peradilan tidak ada gunanya dan hanya merupakan pemborosan uang negara. Harus ada standar indenpendensi hakim dan diimplementasikannya standar tersebut oleh para hakim dan staf pengadilan. Standar independensi pengadilan adalah sebagai berikut:

a. individual judges should enjoy personal independence and substantive independence. Personal independence means that the terms and conditions of judicial service are adequately secured so as to ensure that individual judges are not subject to executive control. Substantive independence means that in the discharge of his/her judicial function a judge is subject to nothing but the law and the commands of his/her conscience;

b. the Judiciary as a whole should enjoy autonomy and collective independence vis-àvis the Executive;

c. participation in judicial appointments and promotions by the executive or legislature is not inconsistent with judicial independence provided that appointments and promotions of judges are vested in a judicial body in which members of judiciary and the legal profession form a majority. Appointments and promotions by a non-judicial body will not be considered inconsistent with judicial independence in countries where, by long historic and democratic tradition, judicial appointments and promotion operate satisfactorily;

d. the Executive may participate in the discipline of judges only in referring complaints against judges, or in the initiation of disciplinary proceedings, but not the adjudication of such matters. The power to discipline or remove a judge must be vested in an institution, which is independent of the Executive. The power of removal of a judge should preferably be vested in a judicial tribunal. The Legislature may be vested with the powers of removal of judges, preferably upon a recommendation of a judicial commission;

e. the Executive shall not have control over judicial functions. ${ }^{7}$

Pernyataan tersebut di atas dapat diartikan sebagai berikut: a. independensi yang harus dipunyai hakim yaitu personal independence dan substantive independence. Independensi personal berarti bahwa keadaan atau situasi pelaksanaan tugas yang aman dan bebas dari pengaruh eksekutif. Independensi substantif berarti bahwa dalam melaksanakan tugas dan kewenangan memeriksa, memutus, dan

7 Anonim, "New-Delhi Standards 1982-New Delhi Code of Minimum Standards of Judicial Independence", https://www.jiwp.org/new-delhi-declaration, diakses tanggal 2 Agustus 2017. 
menyelesaikan sengketa, hakim hanya berdasarkan pada hukum dan keyakinan hati nuraninya; $b$. pengadilan secara keseluruhan harus otonomi dan independen secara kolektif terutama terhadap eksekutif; c. eksekutif tidak diperbolehkan untuk melakukan pengawasan terhadap fungsi pengadilan; d. negara seharusnya memberikan kewajiban kepada eksekutif untuk melaksanakan putusan pengadilan. Pengadilan seharusnya diberikan kekuasaan untuk mengawasi terhadap pelaksanaan atau eksekusi putusan pengadilan; e. gaji dan kenaikannya serta pensiun hakim seharusnya independen dan bebas dari control pemerintah (seksekutif); f. eksekutif seharusnya tidak mempunyai kewenangan untuk menutup atau menunda operasional sistem peradilan pada semua jenjang peradilan.

Meluasnya kewenangan absolut PTUN dalam kenyataannya berpengaruh terhadap independensi hakim PTUN dalam memeriksa, memutus, dan menyelesaikan perkara. Hal ini nyata ditunjukkan pada kasus suap penanganan perkara di PTUN Medan. Kasus tersebut bermula dari gugatan Kepala Biro Keuangan Pemerintah Provinsi Sumatera Utara, Ahmad Fuad kepada Kejaksaan Tinggi Sumatera Utara di PTUN Medan, Sumatera Utara terkait sah atau tidaknya permintaan keterangan terhadap dirinya oleh Kejati Sumut di kasus tersebut. Penggugat berdalih Kejaksaan Tinggi telah menyalahgunakan kewenangan dan tidak sesuai dengan Pasal 1 angka 2 KUHAP dan Undang-Undang Nomor 30 Tahun 2014 tentang Administrasi Pemerintahan.

Dalam kasus tersebut pemohon berkeinginan agar putusan Pengadilan TUN memutuskan bahwa permintaan keterangan (pemeriksaan) terhadap Ahmad Fuad (pemohon) oleh Kejaksaan Tinggi Sumatera merupakan penyalahgunaan wewenang. ${ }^{8}$ Agar putusan Pengadilan TUN Medan sesuai dengan harapan pemohon, maka pemohon lewat pengacaranya berusaha untuk menyuap para hakim dan panitera. Pada tanggal 7 Juli 2015 lalu, Majelis Hakim PTUN Medan yang dipimpin Tripeni Irianto Putro melalui Putusan Pengadilan Tata Usaha Negara Medan Nomor: 25/G/2015/PTUN-MDN, mengabulkan gugatan Ahmad Fuad dan menyatakan bahwa Kejaksaan Tinggi Sumatera Utara telah menyalahgunakan wewenang dalam melakukan tugasnya terkait pemeriksaan

\footnotetext{
8 "KPK Pertimbangkan Ambil Alih Kasus Korupsi Dana Bansos Sumut", http://www.viva.co.id/berita/nasional/654859, diakses tanggal 31 Juli 2017.
} 
Ahmad Fuad dalam kasus dugaan tindak pidana korupsi Dana Bansos Pemerintah Provinsi Sumatera Utara. Inti putusan yaitu pemanggilan termohon (Kejaksaan Tinggi Sumatera Utara) terhadap pemohon (Agus Fuad) dalam Surat Nomor B473/N.2.3/Fd.1/03/2015 tanggal 31 Maret 2015 dinyatakan tidak sah dan ada penyalahgunaan wewenang. ${ }^{9}$

Pemberian uang oleh pihak penggugat karena perkaranya dimenangkan diberikan setelah putusan melalui pengacaranya. Saat penyerahan uang suap tersebut tertangkap tangan oleh Komisi Pemberantasan Korupsi (KPK). Yang tertangkap tangan adalah tiga orang hakim majelis dan panitera yang menerima suap dan pengacara yang menyerahkan uang suap. Kasus tersebut menunjukkan bahwa perluasan kewenangan absolut PTUN berpengaruh terhadap independensi hakim, karena dengan semakin meluasnya kewenangan absolut PTUN semakin besar pengaruh dari pihak-pihak di luar pengadilan. Dalam kasus ini adalah pengaruh dari eksekutif sangat kuat, yaitu pengaruh dari penggugat yaitu Kepala Biro Keuangan Pemerintah Provinsi Sumatera Utara. UU Administrasi Pemerintahan memberikan kompetensi absolut yang semakin luas kepada PTUN, pihak-pihak yang meminta perlindungan hukum kepada PTUN juga semakin luas, tidak hanya warga masyarakat tetapi juga pejabat pemerintahan. Hal ini nampak dalam perkara permohonan ada tidaknya unsur penyalahgunaan wewenang tersebut di atas, di mana pemohonnya adalah Kepala Biro Keuangan Pemerintah Provinsi Sumatera Utara. Tekanan dari berbagai pihak pada PTUN akan semakin meningkat, independensi hakim pun diuji dengan adanya tekanan tersebut. Dalam perkara tersebut, pemohon melakukan tekanan dan intervensi pada hakim supaya memenangkan dirinya. Independensi hakim ternyata melemah, hal ini ditunjukkan dengan terjadinya kasus suap dalam perkara permohonan ada tidaknya unsur penyalahgunaan wewenang yang pertama kali ditangani oleh PTUN Medan tersebut.

Adanya kasus tersebut menunjukkan bahwa keberadaan UU Administrasi Pemerintahan justru memperlemah fungsi PTUN dalam melakukan pengawasan. PTUN mempunyai fungsi melakukan pengawasan terhadap pejabat pemerintahan 
agar tercipta pemerintah yang bersih dan berwibawa. Berdasarkan analisis terhadap kasus tersebut, dengan memenangkan pemohon yang dalam hal ini seorang koruptor dengan cara melakukan suap terhadap para hakim, dalam hal ini PTUN tidak menggunakan fungsi pengawasan untuk mendorong terwujudnya pemerintah yang bersih dan berwibawa, sebaliknya PTUN justru berkontribusi terhadap suburnya praktik korupsi dan kolusi. Belum adanya penyesuaian UU PTUN dengan UU Administrasi Pemerintahan juga menjadi andil semakin lemahnya fungsi PTUN dalam melakukan pengawasan terhadap pemerintah, karena belum ada aturan yang lengkap yang menjadi pedoman bagi hakim dalam memeriksa dan memutus sengketa yang obyeknya diatur dalam UU Administrasi Pemerintahan. Hal ini juga menunjukkan bahwa kurang adanya kepastian hukum dalam penyelesaian sengketa yang kompetensinya diatur dalam UU Administrasi Pemerintahan.

Kelemahan PTUN selama ini di antaranya adalah rendahnya daya paksa pelaksanaan putusan dan budaya kepatuhan pejabat pemerintahan terhadap Putusan PTUN. Berdasarkan analisis Enrico Simanjuntak, faktor-faktor yang mempengaruhi kualitas penegakan hukum di antaranya adalah budaya hukum yang berupa disiplin dan sadar hukum, patuh dan taat terhadap hukum. ${ }^{10}$ Salah satu standar independensi peradilan seperti yang telah disebutkan sebelumnya adalah "Negara seharusnya memberikan kewajiban kepada eksekutif untuk melaksanakan putusan pengadilan. Pengadilan seharusnya diberikan kekuasaan untuk mengawasi terhadap pelaksanaan atau eksekusi putusan pengadilan". Standar tersebut justru yang menjadi kelemahan PTUN hingga saat ini, yaitu bahwa pengadilan tidak mempunyai kekuatan untuk memaksakan agar Putusan PTUN dilaksanakan oleh Pejabat Pemerintahan. Berdasarkan hal tersebut maka dapat disimpulkan bahwa PTUN belum memenuhi standar independensi lembaga peradilan yang ideal. Bertambahnya kompetensi absolut PTUN tanpa diimbangi jaminan pelaksanaan putusan yang dapat dipaksakan justru akan semakin

${ }^{10}$ Enrico Simanjuntak, “Ospek Ombudsman Republik Indonesia Dalam Rangka Memperkuat Pelaksanaan Eksekusi Putusan Peradilan Tata Usaha Negara”, artikel dalam Jurnal Hukum dan Peradilan, Volume 3, Nomor 2 Juli 2014, hlm. 167. 
memperlemah fungsi PTUN sebagai lembaga pengawasan terhadap pemerintahan dan sebagai pengayom masyarakat.

\section{Penguatan Fungsi PTUN Untuk Mengimbangi Semakin Luasnya Kompetensi Absolut PTUN}

PTUN mempunyai fungsi sebagai lembaga pengawasan yuridis terhadap pemerintah. Sebagai lembaga pengawasan, PTUN mempunyai tugas untuk mengawasi pejabat pemerintahan, apakah pejabat pemerintahan dalam membuat keputusan atau melakukan tindakan sesuai dengan perauran perundangundangan dan Asas Umum Pemerintahan yang Baik (AUPB) atau tidak. Pengertian pengawasan dalam bahasa Inggris "Control", dalam bahasa Perancis "Controle", dan dalam bahasa Jerman "Kontrolle", yang artinya "mengawasi" atau “mengendalikan". Meskipun makna pengawasan dan pengendalian ada yang memberikan makna yang berbeda

Berkaitan dengan pengertian pengawasan, Christopher Hood mengatakan sebagai berikut:

Control in the sense used in this book is a synonym for steering or governance. Put abstractly, control is whatever keeps the state of any given system within some desired subset of all its possible states. To evaluate the existence or extent of control in that sense always involves judgement, and the existence of control can never be induced from indices of input or activity. ${ }^{11}$

Pengawasan bisa diartikan sebagai sistem pengendalian. Pengawasan merupakan upaya menjaga keadaan atau sistem tertentu yang diinginkan dari semua keadaan yang mungkin terjadi di luar yang diinginkan. Untuk mengevaluasi adanya atau jangkauan pengawasan diperlukan penilaian, dan adanya pengawasan untuk mengetahui dan menilai adanya kecocokan input atau kegiatan.

Pengertian pengawasan menurut S.P. Siagian adalah sebagai berikut, "Proses pengamatan daripada pelaksanaan seluruh kegiatan organisasi untuk menjamin agar supaya semua pekerjaan yang sedang dilakukan berjalan sesuai dengan

${ }^{11}$ Christopher Hood, at al. (Ed.), Controlling Modern Government Variety, Commonality and Change, Edward Elgar Publishing, Inc., Cheltenham, Massachusetts, 2004, hlm. 6. 
rencana yang telah ditentukan sebelumnya" ${ }^{12}$ Berdasarkan pendapat tersebut, menunjukkan bahwa pengawasan adalah hanyalah kegiatan untuk menjamin kecocokan antara rencana dan pekerjaan yang dilakukan. Pengawasan lebih difokuskan pada kegiatan-kegiatan yang sedang berjalan, jadi pengawasan sifatnya adalab bersifat pencegahan agar ketidakcocokan antara rencana dan kegiatan tidak terjadi.

Victor M. Situmorang dan Jusuf Juhir memberikan pengertian pengawasan sebagai berikut, "Pengawasan adalah setiap usaha dan tindakan dalam rangka untuk mengetahui sejauh mana pelaksanaan tugas yang dilaksanakan menurut ketentuan dan sasaran yang hendak dicapai". ${ }^{13}$

"Control" dalam Bahasa Inggris mempunyai arti "mengawasi" dan "mengendalikan", tetapi sebenarnya antara istilah "pengawasan" dan "pengendalian" itu mempunyai makna yang berbeda. Menurut Muchsan, perbedaan pengawasan dan pengendalian itu adalah sebagai berikut:

Ujud pengawasan adalah kegiatan untuk menilai suatu pelaksanaan tugas secara de facto, sedangkan tujuan pengawasan hanyalah terbatas pada pencocokan apakah kegiatan yang dilaksanakan telah sesuai dengan tolok ukur yang telah ditentukan sebelumnya (dalam hal ini berujud suatu rencana/plan). Dengan demikian dalam kegiatan pengawasan tidak terkandung kegiatan yang bersifat korektif ataupun pengarahan. Itulah sebabnya sarjana membedakan pengertian antara pengawasan dan pengendalian. Pengendalian lebih luas lingkup pengertiannya daripada pengawasan, sebab dalam pengendalian ini di samping kegiatan pengawasan juga meliputi tindakan korektif dan pengarahan. Mudahlah dimengerti apabila sarjana ini membuat suatu hipotesa bahwa pengendalian (DAL) adalah pengawasan (WAS) ditambah dengan tindakan korektif (TK), atau pengawasan (WAS) adalah pengendalian (DAL) yang dikurangi dengan tindakan korektif (TK). ${ }^{14}$

Pengawasan mempunyai makna yang lebih sempit dibandingkan pengendalian. Pengawasan merupakan kegiatan menilai apakah suatu kegiatan itu sesuai dengan rencana yang telah ditentukan dan/atau sesuai dengan peraturan

\footnotetext{
12 S.P. Siagian dalam Victor M. Situmorang dan Jusuf Juhir, Aspek Hukum Pengawasan Melekat Dalam Lingkungan Aparatur Pemerintah, Rineka Cipta, Jakarta, 1994, hlm. 19.

${ }^{13}$ Ibid., hlm. 21.

14 Muchsan, Sistem Pengawasan Terhadap Perbuatan Aparat Pemerintah dan Peradilan Tata Usaha Negara di Indonesia, Liberty, Yogyakarta, 1997, hlm. 38.
} 
perundang-undangan yang berlaku. Pengawasan tidak meliputi kegiatan menindaklanjuti dari hasil pengawasan itu.

Mengenai mekanisme pengawasan, Christopher Hood, dkk., mengatakan sebagai berikut :

In orthodox constitutional theory, the two classical institutional mechanisms for making executive government accountable and keeping it under control in liberaldemocratic states are oversight by elected representatives and legal adjudication by an independent judiciary. ${ }^{15}$

Berdasarkan pendapat Christopher Hood tersebut, ada dua mekanisme pengawasan institusional klasik dalam mengawasi eksekutif atau pemerintah yaitu pengawasan oleh perwakilan terpilih (di Indonesia dikenal dengan lembaga DPR) dan putusan pengadilan yang sah oleh pengadilan independen termasuk di dalamnya PTUN. PTUN merupakan salah lembaga yang fungsinya melakukan pengawasan terhadap pejabat pemerintahan. Apabila dilihat dari makna pengawasan yang bisa mempunyai dua makna pengawasan dan pengendalian, maka sistem PTUN merupakan proses kegiatan melakukan pengawasan terhadap pejabat pemerintahan dalam arti sempit, yaitu pengawasan tanpa dilengkapi dengan kewenangan menindaklanjuti hasil dari pengawasan itu. Tindak lanjut terhadap hasil pengawasan tersebut bukan merupakan bagian dari sistem PTUN itu sendiri. Tindak lanjut terhadap hasil pengawasan PTUN merupakan kewenangan dari eksekutif.

Bertambah luasnya kewenangan absolut PTUN maka semakin besar harapan dari rakyat pencari untuk mendapatkan keadilan melalui PTUN. Dalam hal PTUN dapat memenuhi harapan rakyat untuk mendapatkan keadilan, maka fungsi PTUN menjadi kuat. Ukuran fungsi PTUN itu kuat atau tidak, menurut penulis dapat dilihat dari perlindungan hukum yang adil yang diperoleh rakyat pencari keadilan. Semakin besar kewenangan absolut PTUN dan semakin besar harapan masyarakat terhadap PTUN untuk mendapatkan perlindungan hukum, tetapi sebaliknya daya paksa terhadap pelaksanaan putusan PTUN masih rendah. Hal ini akan

${ }^{15}$ Christopher Hood, at al. (Ed.), Loc. Cit. 
menyebabkan masyarakat tidak mendapatkan perlindungan hukum yang adil dari PTUN, maka ini akan semakin memperlembah fungsi PTUN.

Selain sebagai lembaga pengawasan, PTUN juga mempunyai fungsi sebagai lembaga peradilan. Fungsi peradilan adalah menegakkan hukum dan keadilan yang berlandaskan dasar negara yaitu Pancasila. Lembaga peradilan berfungsi sebagai penegak hukum bertugas untuk memeriksa, mengadili, dan memutus setiap perkara yang diajukan kepadanya agar mendapatkan keadilan. Perkara yang masuk tidak boleh ditolak hakim pengadilan dengan alasan tidak mampu atau tidak ada hukum yang dapat dipakai untuk menyelesaikannya. ${ }^{16}$ Jenis perkara yang masuk disesuaikan dengan tugas dan kewenangan dari tiap lembaga peradilan yang ada. Jadi, melaksanakan kekuasaan kehakiman di Indonesia untuk menegakkan hukum dan keadilan adalah peranan lembaga peradilan.

Lembaga peradilan merupakan lembaga yang berfungsi menegakkan hukum dan keadilan dengan baik, apabila dalam sistem peradilan tersebut ada jaminan bahwa eksekusi putusan dapat dipaksakan, sehingga penggugat benar-benar mendapat perlindungan hukum hingga tuntas, yaitu putusan benar-benar dapat dilaksanakan.

Eksekusi sebagai tindakan hukum yang dilakukan oleh pengadilan kepada pihak yang kalah dalam suatu perkara merupakan aturan dan tata cara pengajuan dari proses pemeriksaan perkara. Hakekat dari eksekusi putusan adalah realisasi kewajiban pihak yang bersangkutan untuk memenuhi prestasi yang tercantum di dalam putusan tersebut. Eksekusi dengan kata lain merupakan pelaksanaan isi putusan hakim yang dilakukan secara paksa dengan bantuan pengadilan, apabila pihak yang kalah tidak mau melaksanakan putusan tersebut secara sukarela. ${ }^{17}$

Daya paksa pelaksanaan atau eksekusi putusan PTUN hingga saat ini masih rendah. Hal ini bisa ditunjukkan berdasarkan hasil penelitian Ihsan Adzillah, bahwa putusan Nomor: 50/G/2014/PTUN-BDG belum dilaksanakan oleh pejabat yang berwenang, salah satunya di antaranya didasarkan pada faktor tidak adanya

${ }^{16}$ Lihat Pasal 10 ayat (1) UU No. 48 Tahun 2009 tentang Kekuasaan Kehakiman, "Pengadilan dilarang menolak untuk memeriksa, mengadili, dan memutus suatu perkara yang diajukan dengan dalih bahwa hukum tidak ada atau kurang jelas, melainkan wajib untuk memeriksa dan mengadilinya.”

${ }^{17}$ Holijah, "Dinamika Penguatan Fungsi Putusan Mahkamah Agung Sebagai Lembaga Peradilan Di Indonesia", http://radenfatah.ac.id/artikel/17, 22 Maret 2017. 
itikad baik dari pihak pemerintah kota Garut maupun pihak pengembang untuk melaksanakan putusan. ${ }^{18}$ Pelaksanaan putusan PTUN diserahkan kepada kesukarelaan pejabat untuk melaksanakannya. Berdasarkan hal tersebut di atas menunjukkan bahwa, pelaksanaan (eksekusi) putusan PTUN bukan merupakan bagian dari fungsi PTUN, tidak seperti lembaga peradilan seperti peradilan perdata, peradilan pidana, peradilan agama, di mana pelaksanaan atau eksekusi putusan merupakan bagian dari sistem peradilan itu sendiri. Dapat disimpulkan bahwa, sistem peradilan tata usaha negara tidak tuntas dalam mengatur proses penyelesaian sengketa hingga eksekusi putusan. Padahal secara umum, semua proses peradilan seperti peradilan perdata, peradilan pidana, dan peradilan agama, mengatur penyelesaian sengketa hingga pengaturan mengenai eksekusinya. Hal ini dapat disimpulkan dari tugas dan wewenang PTUN yaitu “menyelesaikan sengketa TUN".

Fungsi peradilan PTUN dapat dilihat pada tujuan PTUN dalam memberikan perlindungan hukum yang adil bagi pencari keadilan. Fungsi peradilan PTUN nampak pada proses pelaksanaan tugas dan wewenang PTUN dalam memeriksa, memutus dan menyelesaikan sengketa tata usaha negara. Dari proses memeriksa, memutus dan menyelesaikan sengketa tata usaha negara tersebut, pencari keadilan mendapatkan penyelesaian yang memuaskan yaitu gugatan dikabulkan dan putusannya dapat dilaksanakan, sehingga pencari keadilan dapat menikmati kemenangannya. Dalam hal pencari keadilan dapat menikmati kemenangannya, maka dapat dikatakan bahwa pencari keadilan mendapatkan perlindungan hukum yang adil dari proses peradilan tersebut.

Berkaitan dengan fungsi PTUN, Umar Dani mengatakan, "Semangat pembentukan peradilan tata usaha negara di Indonesia lebih kepada menjalankan fungsi pengawasan eksternal pemerintah ketimbang menggali kebenaran materil" ${ }^{19}$ Fungsi pengawasan lebih menonjol pada lembaga PTUN, daripada fungsinya sebagai lembaga peradilan dalam menyelesaikan Sengketa TUN,

18 Ihsan Adzillah, Kajian Pelaksanaan Putusan Pengadilan Tata Usaha Negara Nomor: 50/G/2014/PtunBdg Terhadap Izin Mendirikan Bangunan Pasar Tradisional Limbangan, Skripsi, Fakultas Hukum Universitas Pasundan, Bandung, hlm. v.

${ }^{19}$ Umar Dani, "PTUN dan Kebenaran Formal-Suatu Tinjauan Terhadap Penyelesaian Sengketa Pertanahan di Indonesia”, www.ptun.palembang.go.id, diakses tanggal 9 November 2015, hlm. 1. 
sehingga fungsinya sebagai lembaga peradilan dalam menyelesaikan masalah menjadi kurang kuat. Seharusnya fungsi pengawasan maupun fungsi peradilan tidak dibenturkan satu sama lain, akan tetapi dua-duanya diperhatikan secara seimbang sehingga PTUN berfungsi sebagai lembaga pengawasan maupun sebagai lembaga peradilan sehingga terbentuk lembaga PTUN yang kuat yang mampu menyelesaikan sengketa tata usaha negara secara tuntas.

Ketika fungsi PTUN sebagai lembaga peradilan kurang kuat, maka perlindungan hukum bagi pencari keadilan tidak dapat diwujudkan secara optimal. Manakala pejabat pemerintahan mempunyai kesadaran yang tinggi untuk melaksanakan putusan pengadilan, maka pencari keadilan mendapatkan perlindungan hukum yang adil. Sebaliknya manakala pejabat pemerintahan tidak mempunyai kesadaran untuk melaksanakan putusan maka pencari keadilan tidak akan mendapatkan jaminan perlindungan hukum yang kuat dan tidak mendapatkan keadilan.

Berdasarkan penelitian yang dilakukan tim Pusat Penelitian dan Pembangunan Hukum dan Peradilan Mahkamah Agung, menunjukkan bahwa 93,1 persen menjawab upaya paksa belum efektif menjamin kepatuhan pejabat terhadap putusan PTUN. ${ }^{20}$ Upaya yang pernah dilakukan untuk meningkatkan daya paksa terhadap pelaksanaan Putusan PTUN UU No. 9 Tahun 2004 jo UU No. 51 Tahun 2009 telah mengatur mengenai uang paksa pemerintahan (dwangsom), tetapi ketentuan tentang uang paksa (dwangsom) tersebut tidak dapat dilaksanakan karena belum ada peraturan yang mengatur mengenai mekanisme dalam penerapan uang paksa dan lembaga yang menerapkan uang paksa tersebut. ${ }^{21}$

Selain sanksi berupa uang paksa (dwangsom), juga dapat diterapkan sanksi administratif bagi pejabat yang tidak taat pada putusan. Hal ini juga sudah diatur dalam UU No. 30 Tahun 2014, namun pelaksanaannya juga tergantung pada kesukarelaan pada pejabat pemerintahan atau atasannya. Sepanjang mereka juga tidak melaksanakan, maka tidak ada lembaga atau pejabat yang diberikan wewenang untuk memaksa supaya pejabat melaksanakan putusan.

20 "Penelitian MA 2015: Ius Constituendum Kepatuhan Terhadap Putusan PTUN", www.hukumonline.com, diakses tanggal 12 Juli 2017.

${ }^{21}$ Francisca Romana Harjiyatni, "Peran Jurusita Pada Pengadilan Tata Usaha Negara Setelah Berlakunya UU Nomor 9 Tahun 2004”, artikel dalam Forum Hukum, Volume 12, No. 1, Januari 2008, hlm. 24. 
Untuk mengatasi kelemahan daya paksa pelaksanaan putusan, penelitian yang dilakukan tim Pusat Penelitian dan Pembangunan Hukum dan Peradilan Mahkamah Agung tersebut merekomendasikan diberikannya sanksi pidana terhadap pejabat TUN yang tak mematuhi putusan PTUN yang didukung 74,13 persen responden. Salah satu opsi dalam konteks ini adalah RUU Tindak Pidana Penyelenggaraan Peradilan dan Penghinaan di Luar Pengadilan yang telah disusun Ikatan Hakim Indonesia (Ikahi) dan diserahkan ke Badan Legislasi DPR. RUU ini oleh publik dikenal sebagai RUU Contempt of Court yang menjadi salah satu hukum masa depan yang didambakan bisa mengatasi problem eksekutabilitas putusan TUN yang telah berkekuatan hukum tetap. ${ }^{22}$

Wacana ketidaktaatan pejabat pemerintahan pada putusan PTUN merupakan tindakan contempt of court dianut pula di beberapa negara. Dalam laporan umum kongres di Madrid 2004 disebutkan bahwa "whenever a public official in charge of enforcing the court's decision does not comply with his duty, he will be in contempt of court"23. Dalam hal pejabat yang berwenang tidak mematuhi dan tidak melaksanakan Putusan PTUN, hal tersebut merupakan tindakan contempt of court. Di negara yang menganut konsep tersebut, pada umumnya pejabat pemerintahan taat pada Putusan PTUN, hal ini dinyatakan dalam laporan kongres di Madrid sebagai berikut, "Several reports have outlined the fact that national administrations most frequently abide by administrative court decisions"24. Dapat dikatakan hampir tidak pernah pejabat pemerintahan dikatakan tidak patuh pada Putusan PTUN dan diikategorikan melakukan tindakan contempt of court.

Apabila dicermati dari RUU Contempt of Court, masalah eksekutabilitas putusan belum terakomodir dalam RUU tersebut. Pasal 1 angka 4 RUU Tindak Pidana Penyelenggaraan Peradilan (Contempt Of Court) menyebutkan bahwa, “Setiap orang yang tidak mematuhi perintah pengadilan yang dikeluarkan untuk kepentingan penyelenggaraan peradilan dapat dilakukan penahanan". Ketentuan menjadi lebih kuat didukung dengan ketentuan Pasal 1 angka 4 RUU Tindak

\footnotetext{
22 Ibid.

${ }^{23}$ General Reports Of Congresses, The Execution Of Decisions Of The Administrative Court, International Association Of Supreme Administrative Jurisdictions, VIII ${ }^{\text {th }}$ Congress, Madrid, 2004, hlm. 21.

${ }^{24}$ Ibid., hlm. 22.
} 
Pidana Penyelenggaraan Peradilan (Contempt Of Court) menyebutkan bahwa "Perintah Pengadilan adalah setiap perintah baik yang diberikan secara lisan maupun tertulis oleh hakim atau pengadilan yang ada dalam diktum penetapan atau putusan untuk dipatuhi dan dilaksanakan". Menurut ketentuan-ketentuan tersebut, sepertinya ketidaktaatan melaksanakan putusan pengadilan termasuk dalam ketentuan Pasal 1 angka 4 RUU tersebut, sehingga dapat disimpulkan bahwa ketidaktaatan melaksanakan putusan PTUN merupakan tindakan yang bertentangan dengan ketentuan dalam RUU tersebut dan masuk dalam kategori Tindak Pidana Penyelenggaraan Peradilan.

Apabila dianalisis lebih lanjut berdasarkan ketentuan Pasal 1 angka 4 RUU Tindak Pidana Penyelenggaraan Peradilan (Contempt OfCourt) yang menyebutkan bahwa, "Tindak pidana penyelenggaraan peradilan secara langsung adalah tindak pidana yang dilakukan pada saat dan ketika proses peradilan sedang berlangsung", maka menjadi pertanyaan apakah ketidaktaatan pejabat pemerintahan terhadap putusan PTUN termasuk dalam kategori tindak pidana penyelenggaran peradilan. Hal ini perlu ditinjau lagi berkaitan dengan ketentuan Pasal 5 ayat (1) RUU tersebut. Pasal 5 ayat (1) RUU tersebut menyebutkan bahwa, “Undang-undang ini berlaku untuk semua tingkatan dan lingkungan peradilan”. Pelaksanaan putusan PTUN tidak termasuk dalam lingkup berlakunya RUU tersebut, karena persoalan pelaksanaan putusan bukan lagi menjadi kewenangan Pengadilan TUN. Dengan demikian, ketidaktaatan pejabat pemerintahan terhadap Putusan PTUN bukan tindakan yang bertentangan dengan RUU tersebut dan tidak dapat dikenai sanksi berdasarkan RUU tersebut.

Wacana untuk mengatur bahwa ketidakpatuhan pada putusan PTUN dapat dikenai sanksi pidana bukan merupakan yang mustahil. Ada negara yang memberikan sanksi pidana bagi pejabat pemerintahan yang tidak taat pada putusan. Dalam laporan kongres di Madrid 2004 disebutkan,

As we pointed out in previous pages, imprisonment is a measure attached to legal orders close to English law (see reports from Australia or England and Wales, but also Finland), although it is clear that each system has undergone different experiences. In other States such as Colombia, the arrest of authorities can be an alternative in order to dissuade non-compliance, albeit under specific circumstances (such is the case of constitutional remedies known as "terminating, concluding protection and civil actions"). 
In Austria, civil servants who use their powers in order to breach individual rights, either conscious or unconscious of their actions, will be punished according to the Austrian Criminal Code and judged by the criminal courts.

The Criminal Code will also be implemented in Belgium in specific cases where a civil servant eludes the obligations set out in a court's decision, or in the order of a higher administrative authority. Criminal proceedings can also be initiated when the civil servant eludes an extended time-limit granted by the court. ${ }^{25}$

Laporan Kongres tersebut menunjukkan bahwa negara-negara seperti Inggris, Kolumbia, Austria, dan Belgia menerapkan sanksi pidana pada pejabat pemerintahan yang tidak patuh pada Putusan PTUN. Apapun sanksi yang diberikan pada pejabat pemerintahan baik itu sanksi denda, sanksi pidana maupun sanksi administrasi, ada hal yang tidak bisa ditawar lagi, yaitu adanya lembaga yang mempunyai kewenangan untuk menjamin Putusan PTUN dilaksanakan oleh pejabat pemerintahan. Dalam hal ini perlu dibentuk lembaga eksekusi terhadap Putusan PTUN. Lembaga eksekusi tersebut bisa merupakan lembaga di bawah kekuasaan eksekutif, tetapi lembaga tersebut diberikan kewenangan yang kuat untuk melaksanakan tugasnya yaitu melaksanakan sanksi bagi pejabat pemerintahan yang tidak patuh pada Putusan PTUN.

Untuk penguatan fungsi PTUN yang lain seiring dengan meluasnya kompetensi absolut PTUN adalah dengan menjaga independensi hakim. Untuk menjaga independensi pengadilan pada umumnya dan independensi hakim pada khususnya, maka dapat dimulai dari rekrutmen pegawai pengadilan. Pegawai pengadilan itu tidak hanya mencakup hakim saja, tetapi juga pegawai pengadilan yang lain seperti panitera, karena dalam praktek selama kolusi dengan pengadlan juga melibatkan pegawai pengadilan seperti panitera. Dalam rekrutmen diupayakan untuk dapat menghasilkan pegawai-pegawai pengadilan yang berkualitas dan berintegritas yang tinggi. Berkaitan dengan rekrutmen hakim, Meylin Sihaloho mengatakan sebagai berikut,

Untuk mendapatkan hakim yang memiliki kriteria-kriteria yang memiliki integritas tinggi, disiplin, kepribadian yang tidak tercela, adil, profesional, maka proses seleksi hakim merupakan bagian penting, tanpa adanya proses

${ }^{25}$ Ibid., hlm. 36. 
seleksi pengangkatan hakim akan berdampak pada sistem peradilan yang tidak dapat mewujudkan keadilan dalam penegakan hukum. ${ }^{26}$

Dalam hal rekrutmen menghasilkan hakim-hakim yang memiliki integritas tinggi, berkepribadian baik, professional, pasti akan menjadi hakim yang mempunyai kinerja yang baik dan mampu menyelesaikan kasus dengan adil. Lebih lanjut Meylin Sihaloho mengatakan, "Pelaksanaan seleksi pengangkatan hakim dengan jujur, transparan, dan akuntabel tanpa unsur Korupsi, Kolusi, dan Nepotisme, sehingga mendapatkan calon hakim sesuai kriteria dan mendapatkan kepercayaan masyarakat terhadap sistem hukum di Indonesia".27 Untuk mendapatkan hakim yang berintegritas yang tinggi dan profesional perlu ada inovasi dalam melakukan rekrutmen pegawai pengadilan (rekrutmen dan pengawasan), misalnya rekrutmen dengan melibatkan perguruan tinggi.

Untuk menjaga independensi pengadilan khususnya independensi hakim, maka perlu ditingkatkan pengawasan terhadap kinerja pegawai pengadilan. Pengawasan terhadap kinerja hakim selama ini kewenangannya telah diberikan kepada Komisi Yudisial. Secara kelembagaan Komisi Yudisial mempunyai keterbatasan dalam mengawasi perilaku hakim. Hal ini ditunjukkan dalam pernyataan berikut,

Kehadiran Komisi Yudisial (KY) dipandang mampu menjawab masalah internal yang dihadapi Mahkamah Agung sebagai pemegang kekuasaan kehakiman tertinggi hingga tingkat bawah. Bahkan keberadaan KY sanggup melompat jauh dijaga penegakkan hukum, khususnya pengawasan terhadap perilaku hakim. Pada awal kehadirannya tidak banyak yang memperkirakan KY akan mampu menjaga dan menegakan kehormatan, keluhuran martabat hakim serta perilaku hakim. Mengingat kewenangan ini mempunya arti yang sangat luas. Secara sempit wewenang ini dapat digambarkan sebagai wewenang pengawasan hakim terutama perilaku hakim. Wewenang tersebut masih sangat besar jika dibandingkan kedudukan kelembagaan KY yang hanya ada di Jakarta sebagai ibukota negara. Namun wewenang dan tugasnya menjangkau seluruh wilayah Indonesia. ${ }^{28}$

${ }^{26}$ Meylin Sihaloho, "Seleksi Pengangkatan Hakim Dalam Sistem Peradilan Indonesia: Kajian Putusan Mahkamah Konstitusi Nomor 43/PUU-XII/2015”, artikel dalam Jurnal Wawasan Hukum, Vol. 33, No. 2, September 2015, hlm. 205.

${ }^{27}$ Ibid., hlm. 217.

${ }_{28}$ Majalah Komisi Yudisial dalam Ahmad, "Fungsi Pengawasan Komisi Yudisial : Independensi Hakim Bukan Sebagai Hak Melainkan Kewajiban”, Prosiding: Sinergitas Mahkamah Agung dan Komisi Yudisial dalam Mewujudkan Excellent Court 6 Mei 2017 M/9 Sya’ban 1438 H, Aula A.K. Anshori - Universitas Muhammadiyah Purwokerto, hlm. 106. 
Komisi Yudisial perlu meningkatkan pengawasannya terhadap kinerja hakim, karena dengan semakin meluasnya kompetensi absolut PTUN akan semakin besar tekanan maupun intervensi terhadap hakim dalam menjalankan tugasnya memeriksa dan mengadili perkara yang diajukan kepadanya. Melihat kewenangan absolut PTUN yang semakin besar dan semakin rentan terhadap intervensi dari para pihak, untuk itu perlu dibentuknya perwakilan Komisi Yudisial di daerah, sehingga Komisi Yudisial dapat melakukan pengawasan terhadap hakim-hakim di daerah.

Selain pengawasan terhadap kinerja hakim, perlu juga dilakukan pengawasan terhadap pegawai pengadilan yang lain seperti panitera pengadilan, karena kolusi dalam badan pengadilan pada prakteknya juga dilakukan oleh pegawai pengadilan lain selain hakim. Yang menjadi pertanyaan adalah siapakah yang mengawasan perilaku pegawai pengadilan lain selain hakim. Ketua Pengadilan bisa menggunakan kewenangannya untuk melakukan pengawasan melekat terhadap para pegawai pengadilan sebagai bawahannya, namun untuk dapat mengawasi bawahannya Ketua Pengadilan juga dituntut untuk mempunyai integritas yang tinggi sebagai hakim. Pengawasan terhadap pegawai pengadilan selain hakim dapat pula dilakukan oleh Menteri Hukum dan HAM, karena secara organisatoris pegawai pengadilan berada di bawah Kementerian Hukum dan HAM.

\section{Penutup}

Berangkat dari hasil penelitian yang telah diuraikan di atas, maka dapat disimpulkan, pertama, diberlakukannya UU No. 30 Tahun 2014, kompetensi absolut PTUN menjadi semakin luas. Hal ini menimbulkan implikasi memperlemah atau menguatkan fungsi PTUN. Dengan meluasnya kompetensi absolut PTUN maka tuntutan masyarakat akan perlindungan hukum kepada PTUN menjadi semakin tinggi. Fungsi PTUN menjadi lembaga pengawasan yang semakin kuat dalam PTUN mampu memberikan perlindungan bagi masyarakat yang dirugikan oleh pejabat pemerintahan. Seiring dengan semakin luasnya kompetensi absolut PTUN, fungsi PTUN akan menjadi semakin kuat apabila: 1) fungsi PTUN ditunjang dengan pengaturan pelaksanaan (eksekusi) putusan yang lebih mempunyai daya paksa. Akan menjadi sia-sia ketika semakin banyak warga masyarakat yang memohon 
perlindungan hukum kepada PTUN akan tetapi sebaliknya putusan PTUN tidak dapat dipaksakan berlakunya; 2) Independensi pengadilan dan hakim-hakimnya dapat dijaga sehingga PTUN mampu membentengi dirinya dari pengaruh, tekanan, campur tangan dari lembaga lainya maupun dari para pihak yang berperkara.

Kedua, perlu penguatan fungsi PTUN sebagai lembaga pengawasan maupun lembaga peradilan seiring dengan meluasnya kompetensi PTUN berdasarkan UU Administrasi Pemerintahan. Penguatan fungsi PTUN dilakukan dengan cara: 1) Merubah UU PTUN untuk disesuaikan dengan UU Administrasi Pemerintahan dan meningkatkan daya paksa pelaksanaan putusan dengan membentuk lembaga eksekusi untuk melaksanakan putusan PTUN; 2) meningkatkan independensi hakim PTUN dalam memeriksa, memutus dan menyelesaikan sengketa atau permohonan.

Adapun hasil penelitian yang telah diuraikan di atas penulis dapat memberikan sarana, Pertama, peningkatan pengawasan terhadap hakim PTUN untuk menjaga dan meningkatkan independensi hakim PTUN dalam menjalankan tugasnya. Kedua, mengganti UU PTUN untuk menyesuaikan dengan UU Administrasi Pemerintahan

\section{Daftar Pustaka}

\section{Buku}

Hood, Christopher, at al. (Ed.), Controlling Modern Government Variety, Commonality and Change, Edward Elgar Publishing, Inc., Cheltenham, Massachusetts, 2004.

Mertokusumo, Sudikno, Mengenal Hukum Suatu Pengantar, Cetakan Keempat, Liberty, Yogyakata, 2008.

Muchsan, Sistem Pengawasan Terhadap Perbuatan Aparat Pemerintah dan Peradilan Tata Usaha Negara di Indonesia, Liberty, Yogyakarta, 1997.

Siagian, S.P., (dalam Victor M. Situmorang dan Jusuf Juhir), Aspek Hukum Pengawasan Melekat Dalam Lingkungan Aparatur Pemerintah, Rineka Cipta, Jakarta, 1994.

Simanjuntak, Enrico, “Beberapa Anotasi Terhadap Pergeseran Kompetensi Absolut Peradilan Umum Kepada Peradilan Administrasi Pasca Pengesahan UU No. 30 Tahun 2014", Bunga Rampai Peradilan Administrasi Kontemporer, Genta Press, Yogyakarta, 2014. 


\section{Hasil Penelitian/Tugas Akhir}

Adzillah, Ihsan, Kajian Pelaksanaan Putusan Pengadilan Tata Usaha Negara Nomor: 50/G/2014/Ptun-Bdg Terhadap Izin Mendirikan Bangunan Pasar

Tradisional Limbangan, Skripsi, Fakultas Hukum Universitas Pasundan, Bandung. 2017.

\section{Jurnal}

Heryansyah, Despan, "Pergeseran Kompetensi Absolut PTUN Dalam Sistem Hukum Indonesia”, Jurnal Hukum Novelty, Vol. 8 No. 1 Februari 2017.

Martono Wahyunadi, Yodi, "Kompetensi Absolut Pengadilan Tata Usaha Negara Dalam Konteks Undang-Undang Nomor 30 Tahun 2014 tentang Administrasi Pemerintahan", Jurnal Hukum dan Peradilan, Volume 5, Nomor 1, Maret 2016.

Romana Harjiyatni, Francisca, "Peran Jurusita Pada Pengadilan Tata Usaha Negara Setelah Berlakunya UU Nomor 9 Tahun 2004", Forum Hukum, Volume 12, No. 1, Januari 2008.

Sihaloho, Meylin, "Seleksi Pengangkatan Hakim Dalam Sistem Peradilan Indonesia: Kajian Putusan Mahkamah Konstitusi Nomor 43/Puu-Xii/2015", Jurnal Wawasan Hukum, Vol. 33, No. 2, September 2015.

Simanjuntak, Enrico, “Ospek Ombudsman Republik Indonesia Dalam Rangka Memperkuat Pelaksanaan Eksekusi Putusan Peradilan Tata Usaha Negara", Jurnal Hukum dan Peradilan, Volume 3, Nomor 2 Juli 2014.

\section{Makalah/Pidato}

Ahmad, "Fungsi Pengawasan Komisi Yudisial : Independensi Hakim Bukan Sebagai Hak Melainkan Kewajiban", Prosiding : Sinergitas Mahkamah Agung dan Komisi Yudisial dalam Mewujudkan Excellent Court 6 Mei 2017 M/9 Sya'ban 1438 H, Aula A.K. Anshori - Universitas Muhammadiyah Purwokerto.

General Reports Of Congresses, The Execution Of Decisions Of The Administrative Court, International Association Of Supreme Administrative Jurisdictions, VIIIth Congress, Madrid, 2004.

\section{Internet}

“Dinamika Penguatan Fungsi Putusan Mahkamah Agung Sebagai Lembaga Peradilan Di Indonesia", http://radenfatah.ac.id/artikel/17, diakses tanggal 22 Maret 2017.

"KPK Pertimbangkan Ambil Alih Kasus Korupsi Dana Bansos Sumut", http:/ / www.viva.co.id/berita/nasional/654859, diakses tanggal 31 Juli 2017.

"New-Delhi Standards 1982-New Delhi Code of Minimum Standards of Judicial Independence", https://www.jiwp.org/new-delhi-declaration, diakses tanggal 2 Agustus 2017. 
"Penelitian MA 2015: Ius Constituendum Kepatuhan Terhadap Putusan PTUN", www.hukumonline.com, diakses tanggal 12 Juli 2017.

"PTUN dan Kebenaran Formal-Suatu Tinjauan Terhadap Penyelesaian Sengketa Pertanahan di Indonesia", www.ptun.palembang.go.id, diakses tanggal 9 November 2016.

"Why is Judicial Independence Important to You?", http://www.cjcccm.gc.ca/cmslib/general, diakses tanggal 27 Juli 2017. 